\section{Direct Seeding Short-day Onions in Southeastern Georgia}

\author{
George E. Boyhan ${ }^{1,6}$, Juan Carlos Diaz-Perez ${ }^{2}$, Chris Hopkins ${ }^{3}$, \\ Reid L. Torrance ${ }^{4}$, and C. Randy Hill ${ }^{5}$
}

ADDITIONAL INDEX WORDs. spring onions, non-storage onions, seed treatment, Vidalia onions

\begin{abstract}
Summary. Onions (Allium cepa) in southeastern Georgia are almost exclusively transplanted, with the associated high costs and labor requirements. This study was undertaken to evaluate direct-seeded onions as an alternative production method. This study evaluates variety, sowing date, and fertility on direct seeding short-day onions in southeastern Georgia. Sowing dates, early or mid-October ( 5 and 15 Oct. 2001 and 7 and 21 Oct. 2002), did not affect total, jumbo ( $\geq 3$ inches diameter), or medium ( $\geq 2$ inches and $<3$ inches diameter) yields. Late October sowing (29 Oct. 2001 ) did not produce sufficient stand or yield to warrant harvesting. Variety also had no affect on yield of direct-seeded onions. Seedstems (flowering), an undesirable characteristic, was significantly greater with the early October sowing date across all varieties compared with the mid- or late- October sowing dates.

Neither variety nor sowing date significantly affected plant stand or plant spacing. Fertilization treatments of 150 or $195 \mathrm{lb}$ /acre nitrogen $(N)$ with various application timings and fertilizer sources did not affect total or medium yields. Jumbo yield was affected in only 1 year with calcium nitrate as the primary $N$ source at $195 \mathrm{lb} / \mathrm{acre}$ total $\mathrm{N}$ having the highest yield, but did not differ from some treatments at $150 \mathrm{lb} /$ acre $\mathrm{N}$. In addition, fertilization treatments did not affect seedstems, plant stand, or plant spacing. Based on this study, we are recommending that growers should direct seed onions in southeastern Georgia in mid-October, plus or minus 1 week depending on field accessibility. In addition, current fertilizer recommendations for transplanted dry bulb onions should be followed, which includes $150 \mathrm{lb} /$ acre $\mathrm{N}$. This eliminates all of the cost and resources required for transplant production.
\end{abstract}

$\mathrm{O}$ nion production in the Vidalia production region of southeastern Georgia has traditionally used transplants to produce dry bulb onions. Transplants are grown on-farm in high-density plantings, which are then pulled and transplanted to their final spacing (Boyhan et al., 2001a). All of this relies on hand labor, which adds to the cost of production. Current University of Georgia Cooperative Extension Service fertilizer recommendations for onions includes $130 \mathrm{lb} /$ acre $\mathrm{N}$ for

\footnotetext{
${ }^{1}$ Associate Professor, Extension Horticulturist-Vegetables, Department of Horticulture, University of Georgia, East Georgia Extension Center, P.O. Box 8112 , GSU, Statesboro, GA 30460

${ }^{2}$ Associate Professor. Department of Horticulture, University of Georgia, Coastal Plain Experiment Station, P.O. Box 748, Tifton, GA 31794

${ }^{3}$ Former County Agent, currently Agronomist with Bayer CropScience. Toombs County Cooperative Extension Service, 200 Courthouse Square, Suite 1, Lyons, GA 30436

${ }^{4}$ County Extension Coordinator. Tattnall County Cooperative Extension Service, P.O. Box 580, Reidsville, GA 30453

${ }^{5}$ Farm Superintendent. Vidalia Onion and Vegetable Research Center, 8163 Hwy. 178, Lyons, GA 30436

${ }^{6}$ Corresponding author. E-mail: gboyhan@uga.edu.
}

transplant production and an additional $150 \mathrm{lb} /$ acre $\mathrm{N}$ for dry bulb production (Boyhan et al., 2001a). The total $\mathrm{N}$ requirement of $280 \mathrm{lb} /$ acre is the highest for any vegetable in Georgia, which might be reduced with direct-seeded onions (Kissel, 2003). Furthermore, the Texas Agricultural Extension Service recommends $120 \mathrm{lb} /$ acre $\mathrm{N}$ to produce direct-seeded onions, which further supports the possibility of reducing fertilizer requirements (Hall et al., 2000).

A variety of studies have been conducted to evaluate direct seeding, transplanting, and using sets to produce onions. Comparisons of directseeded, bare root transplants and 228-cell flat production has been conducted where plants from cell flats with one plant per cell produced the greatest percentage of jumbo onions ( $\geq 3$ inches diameter) compared with bare root plants or cell flats with three plants per cell (Leskovar et al., 2004).

Sowing date has been shown to affect yield with transplanted onions. Onions sown on 10 Aug. had greater yield with 'Agrifound Dark Red' in Junagadh, India, compared with 25 Aug. or 9 Sept. sowing dates (Movalia et al., 1999). In a study in Egypt evaluating direct-seeded onions, it was found that those sown on 20 Sept. had higher yields compared with those sown on 23 Aug. or 18 Oct. (Gamie et al., 1996). Transplanted onions were found to have greater yields and increased bulb size compared with direct seeding in a study in India among different varieties (Khokhar et al., 1990). In a comprehensive study of onion varieties and sowing dates in New Mexico from 9 to 30 Sept., it was found that delayed sowing resulted in less bolting, greater yield, and delayed maturity (Cramer, 2003). Bolting resistance in 'NuMex Mesa' played a greater role than sowing date on having lower numbers of seedstems regardless of sowing date.

Transplant age and days after transplanting have been investigated for their effect on yield. In Nasik, Maharashtra, India, 'Agrifound Light Red' was found to have the greatest yield from 8-week-old transplants harvested $125 \mathrm{~d}$ after transplanting compared with 7- or 9-week-old transplants and harvest dates of 110 and $140 \mathrm{~d}$ after transplanting (Bhonde et al., 2001).

Fertilizers and sowing date have been evaluated with variety $\mathrm{Al}$-Hassawi in Saudi Arabia (Al-Abdulsalam and Hamaiel, 2004). It was found that a 20 Oct. sowing date with fertilizer formulation $14 \mathrm{~N}-16.6 \mathrm{P}-$ $8.3 \mathrm{~K}$ gave the best yields compared

\begin{tabular}{llll}
\hline $\begin{array}{l}\text { Units } \\
\text { To convert U.S. to SI, } \\
\text { multiply by }\end{array}$ & U.S. unit & SI unit & $\begin{array}{l}\text { To convert SI to U.S., } \\
\text { multiply by }\end{array}$ \\
\hline 0.4047 & $\mathrm{acre}(\mathrm{s})$ & $\mathrm{ha}$ & 2.4711 \\
0.3048 & $\mathrm{ft}$ & $\mathrm{m}$ & 3.2808 \\
3.7854 & $\mathrm{gal}$ & $\mathrm{L}$ & 0.2642 \\
2.54 & inch(es) & $\mathrm{cm}$ & 0.3937 \\
1.1209 & $\mathrm{lb} / \mathrm{acre}$ & $\mathrm{kg} \cdot \mathrm{ha}^{-1}$ & 0.8922 \\
$\left({ }^{\circ} \mathrm{F}-32\right) \div 1.8$ & ${ }^{\circ} \mathrm{F}$ & ${ }^{\circ} \mathrm{C}$ & $\left(1.8 \times{ }^{\circ} \mathrm{C}\right)+32$
\end{tabular}

\footnotetext{
Haring
} 
with 20 Sept. or 20 Nov. sowing dates and fertilizers $20 \mathrm{~N}-8.7 \mathrm{P}-16.6 \mathrm{~K}$, $19 \mathrm{~N}-12.7 \mathrm{P}-9.1 \mathrm{~K}$, or $16 \mathrm{~N}-3.9 \mathrm{P}-$ 21.6K. Brewster (1990) found in the United Kingdom that earlier sowing, greater plant density, and various fertilizer rates accelerated bulb development across locations and years. This was attributed to larger leaf area index and accumulation of thermal time (degree days).

Texas is the closest region to southeastern Georgia in terms of environment for onion production. However, Texas has several regions of production, including the Lower Valley on the Mexican border, the Winter Garden northwest of the Lower Valley, the Trans-Pecos in western Texas, and the High Plains in northern Texas (Hall et al., 2000). Their recommendations for sowing dates extend from October to March, with short-day, intermediate-day, and longday onion varieties, depending on the region.

The studies cited above indicate that geographic location is important in determining the optimum sowing date with different varieties evaluated at each location. In addition, fertilizer interaction with sowing date is an important factor in onion development.

Because of the relative higher cost of transplant production, primarily because of greater labor requirements, compared with direct seeding, coupled with the potential lack of labor, this study was undertaken to evaluate effects of sowing date, variety, and fertility on direct seeding short-day onions in southeastern Georgia with the aim that this might lower overall production costs.

\section{Materials and methods}

VARIETY AND SOWING DATE EXPERIMENTS. In 2001, coated seeds (Filmcoat Plus; Harris Moran Seed Co., Modesto, CA) were sown on three different dates with a Monosem vacuum planter (model 540; Monosem Corp., Lenexa, KS). A 36-hole plate was used and the planter was set to $\mathrm{B} 2$ for a $5^{3} / 8^{-}$-inch in-row spacing, according to the owner's manual. The between-row spacing was set to 12 inches. Four rows were planted per bed with beds formed on 6 - $\mathrm{ft}$ centers. This would result in $\approx 65,000$ plants per acre. Insect, disease, weed control, and fertilization followed
University of Georgia Cooperative Extension Service recommendations (Boyhan et al., 2001a). Plants were irrigated with drip irrigation that used two drip tapes (4-inch emitter spacing, $24 \mathrm{gal} / \mathrm{h}$ per $100 \mathrm{ft}$ ) per bed.

The experiment was arranged in a split-block design with the sowing date being the main plot effect and variety as the subplot effect. About $450 \mathrm{ft}$ of row was sown for each variety on each date and for each replication. The sowing dates were 5, 15, and 29 Oct. 2001. Each bed was planted with four varieties: Pegasus, Sweet Vidalia, Nirvana, and PS 7092. With two of the replications, 'Pegasus' and 'PS 7092' were planted to the outside rows with 'Sweet Vidalia' and 'Nirvana' planted to the inside rows. This was reversed with the other two replications. Each experimental unit was a single row of onions $50 \mathrm{ft}$ in length. Onion seed sown on 5 Oct. 2001 were harvested on $30 \mathrm{Apr}$. 2002, and onions sown on 15 Oct. 2001 were harvested on 9 May 2002. Onions sown on 29 Oct. 2001 did not have sufficient stand or size to warrant harvesting.

At harvest, onions had their tops and roots removed before being immediately weighed in the field. Bulbs were then heat cured for a minimum of $24 \mathrm{~h}$ at $95{ }^{\circ} \mathrm{F}$. Bulbs were then graded into jumbo $(\geq 3$ inches diameter) and medium ( $\leq 2$ inches and $<3$ inches diameter) size classes and these weights were recorded (U.S. Department of Agriculture, 1995).

Onion stand and in-row spacing were measured on 7 Jan. 2002 for two 3 -ft sections for each variety and sowing date within each replication. These data were used to report plant stand and the in-row spacing as the percentage below 4 inches and above 6.5 inches. Seedstems were recorded for a 50 - $\mathrm{ft}$ section of row on 14 May 2002 among onions remaining in the field.

In the second year (2002), coated onion seeds were sown in a similar fashion to 2001 with varieties Pegasus, Sweet Vidalia, Nirvana, and Century. 'Century' was substituted for 'PS 7092' because 'PS 7092' was discontinued. 'Century' is in the same maturity class as 'PS 7092' and from the same seed company. Onions were sown on 7 and 21 Oct. 2002. The experiment was arranged in a split- plot design with the sowing date as the main plot effect and variety as the subplot effect. There were four replications with the experimental unit a single row $20 \mathrm{ft}$ long. Cultural practices were the same as for the previous year.

Plant spacing for the first sowing date $(7$ Oct.) was measured on two 3$\mathrm{ft}$ sections for each experimental unit on 23 Jan. 2003. For the second sowing date, plant spacing was measured on 24 Mar. 2003. The number of seedstems or flowers was recorded for each experimental unit on 29 Apr. 2003. Onions were harvested on 1 May 2003 and were immediately weighed. Bulbs were then heat cured, graded, and weighted as in 2002.

FerTILITY EXPERIMENTS. Experiments in the 2003-04 and 2004-05 seasons were arranged in randomized complete block design of four replications with all treatments receiving a base rate of $800 \mathrm{lb} /$ acre of $5 \mathrm{~N}-4.3 \mathrm{P}-$ $12.4 \mathrm{~K}$ with $9 \%$ sulfur $(\mathrm{S})$ applied preplant and incorporated. This resulted in $40 \mathrm{lb} /$ acre N, $35 \mathrm{lb} /$ acre phosphorus, $100 \mathrm{lb} /$ acre potassium, and 72 $\mathrm{lb} /$ acre S, respectively. In 2003-04, encrusted seed (Onx encrustation; Incotec, Salinas, CA) of varieties Granex Yellow PRR and Savannah Sweet were sown on 13 Oct. 2003 with a Monosem vacuum planter (36-hole plate, set to C3) on beds formed on 6 - $\mathrm{ft}$ centers with four rows spaced 12 inches apart and with an in-row spacing of 4 inches. 'Yellow Granex PRR' seeds were sown for replications $l$ and 3 and 'Savannah Sweet' seeds were sown for replications 2 and 4 . This was done because we had insufficient coated seeds of either variety for the entire trial. In 2004-05, coated seeds of variety Century were sown on 13 Oct. 2004 for the entire experiment. All the seeds for both years were obtained from a local grower and represent midseason, short-day onion varieties in the Vidalia onion-growing region of southeastern Georgia. The experimental unit was $30 \mathrm{ft}$ of planted bed in 2003-04 and $20 \mathrm{ft}$ of planted bed in 2004-05. In both years, weed, disease, and insect control and cultural practices followed University of Georgia Cooperative Extension Service recommendations (Boyhan et al., 200la).

Treatments are listed in Table 1. "Low frequency" refers to those treatments that had no fertilizer 
Table 1. Treatment list for fertility experiment of direct-seeded onions with application dates, material used, and amount applied. ${ }^{\mathrm{z}}$

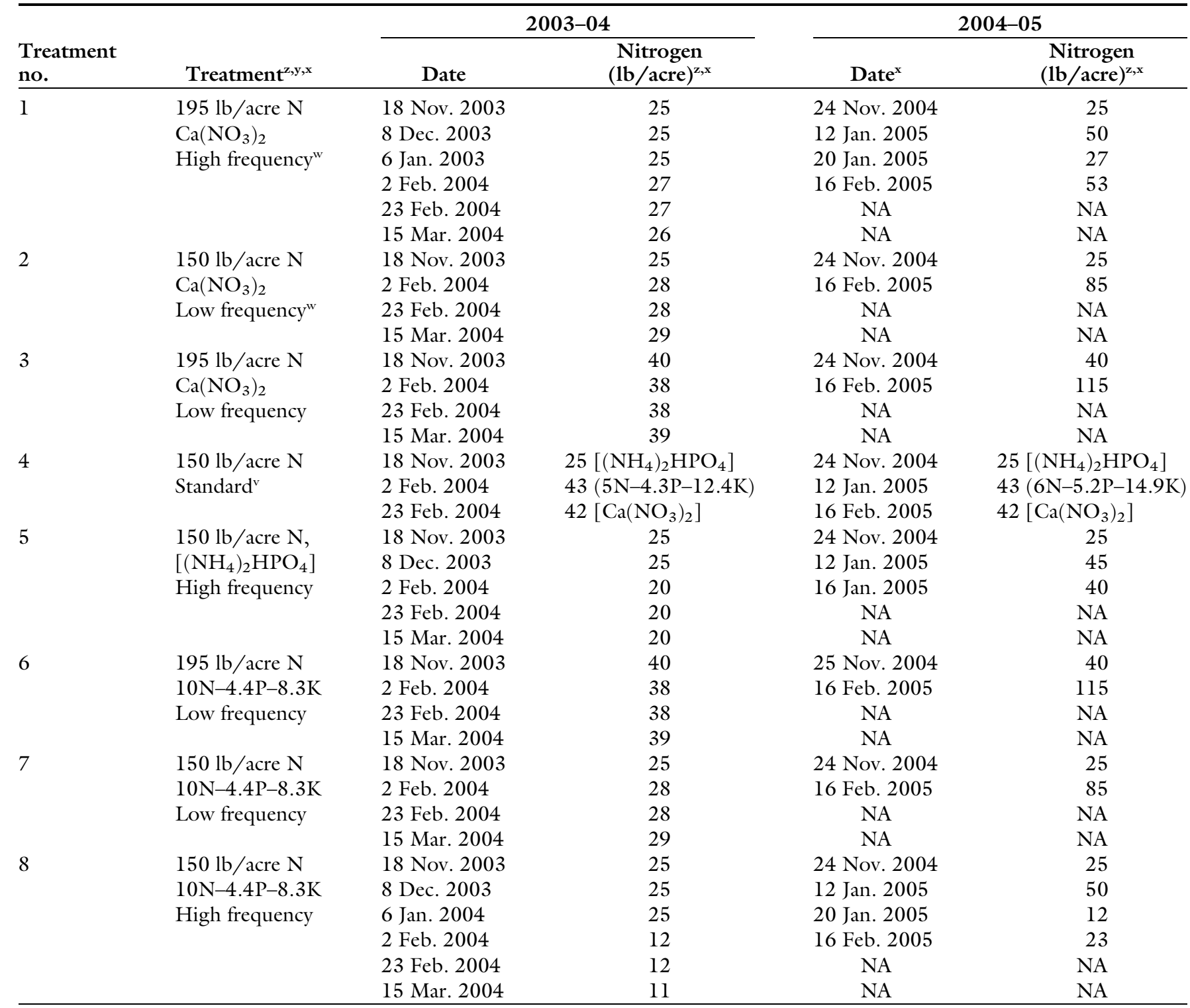

${ }^{\mathrm{z}}$ All treatments had $800 \mathrm{lb} /$ acre $\left(1 \mathrm{lb} /\right.$ acre $\left.=1.1209 \mathrm{~kg} \cdot \mathrm{ha}^{-1}\right) 5 \mathrm{~N}-4.3 \mathrm{P}-12.4 \mathrm{~K}$ with $9 \%$ sulfur applied preplant and incorporated. Sowing dates were $13 \mathrm{Oct}$. 2003 and 13 Oct. 2004.

${ }^{\mathrm{y}}$ Nitrogen $(\mathrm{N})$ fertilizer amount, $\mathrm{N}$ source, and application frequency.

${ }^{\mathrm{x}} \mathrm{Ca}\left(\mathrm{NO}_{3}\right)_{2}=$ calcium nitrate, $\left(\mathrm{NH}_{4}\right)_{2} \mathrm{HPO}_{4}=$ diammonium phosphate, $\mathrm{NA}=$ not applicable.

wHigh frequency indicates fertilizer application in December or January, low frequency indicates no fertilizer in December and January.

v'Standard is similar to current recommended fertilization with fertilizer source listed in nitrogen columns (Boyhan et al., 200la).

applied during December and January, and "high frequency" refers to treatments that had fertilizer applied in December and January. The standard treatment included materials and applications common to the Vidalia region (Boyhan et al., 2001a). This included $5 \mathrm{~N}-4.3 \mathrm{P}-12.4 \mathrm{~K}$, calcium nitrate $\left[\mathrm{Ca}\left(\mathrm{NO}_{3}\right)_{2}\right]$, and diammonium phosphate $\left[\left(\mathrm{NH}_{4}\right)_{2} \mathrm{HPO}_{4}\right]$.

Plant spacing was measured on two randomly chosen 3 -ft row sections for each experimental unit. This was done on 13 Jan. 2004 and 28 Feb. 2005. The percentage of onions with spacing below 4 inches and above 6.5 inches was calculated and reported. Seedstem numbers for the entire experimental unit or plot were recorded on 22 Apr. 2004. There were too few seedstems in 2005 to collect meaningful data.

In 2004, onions were harvested on 11 May, and in 2005, onions were harvested on 31 May. Weights were recorded in the field after tops and roots were removed. Onions were then graded into jumbo $(\geq 3$ inches diameter) and medium ( $\geq 2$ inches and $<3$ inches diameter) size classes.
Data were analyzed with Excel 11.3.5 (Microsoft Corp., Redmond, WA) and Stata 9.2 (StataCorp, College Station, TX). The sowing date/ variety split-plot experiments were analyzed assuming years as a random factor with varieties and sowing dates as fixed factors (Gomez and Gomez, 1984).

\section{Results and discussion}

There was no difference in total yield because of variety or sowing date (Table 2). In addition, there was no treatment by year interactions for 
Table 2. Effect of variety and sowing date on yield, graded yield, seedstem formation (flowering), plant stand, and plant spacing in direct-seeded onions for the 2001-02 and 2002-03 seasons.

\begin{tabular}{|c|c|c|c|c|c|c|c|c|c|}
\hline \multirow[b]{3}{*}{ Variety } & \multirow{3}{*}{$\begin{array}{c}\text { Sowing } \\
\text { date }^{\mathrm{z}}\end{array}$} & \multirow{3}{*}{$\begin{array}{c}\text { Total } \\
\text { yieldy }^{\mathrm{y}}\end{array}$} & \multirow{2}{*}{ Jumbo $^{y}$} & \multirow{3}{*}{$\frac{\text { Medium }^{y}}{)^{\mathrm{x}}}$} & \multirow{2}{*}{\multicolumn{2}{|c|}{ Seedstems }} & \multirow{2}{*}{$\begin{array}{l}\text { Plant } \\
\text { stand }\end{array}$} & \multicolumn{2}{|c|}{ Plant spacing } \\
\hline & & & & & & & & $\begin{array}{c}\text { Below } \\
4 \text { inches }^{x} \\
\end{array}$ & $\begin{array}{c}\text { Above } \\
6.5 \text { inches }\end{array}$ \\
\hline & & & (lb/acre & & \multicolumn{2}{|c|}{$\frac{2002}{2003}$} & $(\text { no./3-ft row })^{x}$ & --.--n-- & \%) ----- \\
\hline \multirow[t]{3}{*}{ Pegasus } & Early & 26,671 & 12,802 & 3,004 & 9.3 & 0.8 & 5.5 & 10 & 14 \\
\hline & Mid & 23,134 & 8,552 & 4,908 & 0.3 & 0.0 & 6.2 & 11 & 19 \\
\hline & Late & - & - & - & 0.0 & - & 5.4 & 0 & 33 \\
\hline & Mid & 31,145 & 15,788 & 5,043 & 1.5 & 0.0 & 6.9 & 14 & 11 \\
\hline & Late & - & - & - & 0.0 & - & 5.9 & 12 & 28 \\
\hline \multirow[t]{3}{*}{ Nirvana } & Early & 25,308 & 11,689 & 4,138 & 7.0 & 1.0 & 5.5 & 14 & 18 \\
\hline & Mid & 18,578 & 6,701 & 5,234 & 0.0 & 0.0 & 6.1 & 10 & 19 \\
\hline & Late & - & - & - & 0.3 & - & 4.3 & 7 & 40 \\
\hline \multirow[t]{9}{*}{ PS $7092^{v}$} & Early & 31,152 & 13,920 & 2,604 & 8.8 & 0.3 & 5.8 & 19 & 17 \\
\hline & Year & 0.829 & 0.016 & 0.010 & \multicolumn{2}{|c|}{0.017} & 0.699 & 0.028 & 0.401 \\
\hline & Variety & 0.073 & 0.314 & 0.738 & \multicolumn{2}{|c|}{0.528} & 0.072 & 0.328 & 0.110 \\
\hline & Year $\times$ Variety & 0.682 & 0.430 & $0.047^{\mathrm{u}}$ & \multicolumn{2}{|c|}{$0.021^{\mathrm{u}}$} & 0.101 & $0.030^{\mathrm{w}}$ & 0.612 \\
\hline & Sowing Date & 0.206 & 0.188 & 0.346 & \multicolumn{2}{|c|}{0.523} & 0.167 & 0.104 & 0.152 \\
\hline & Year $\times$ Date & 0.526 & 0.820 & 0.110 & \multicolumn{2}{|c|}{0.029} & 0.627 & 0.938 & 0.712 \\
\hline & Variety $\times$ Date & 0.316 & 0.614 & 0.468 & \multicolumn{2}{|c|}{0.314} & 0.280 & $0.030^{\mathrm{w}}$ & 0.318 \\
\hline & Sowing date 2002 & & & & \multirow{2}{*}{\multicolumn{2}{|c|}{0.000}} & & & \\
\hline & Sowing date 2003 & & & & & & & & \\
\hline
\end{tabular}

${ }^{\mathrm{z}}$ Sowing dates for the 2001-02 season: Early $=5$ Oct. 2001 , mid = 15 Oct. 2001 , late $=29$ Oct. 2001 . Sowing dates for the $2002-03$ season: Early $=7$ Oct. 2002 , mid $=21$ Oct. 2002 .

Jumbo $\geq 3$ inches diameter, medium $\geq 2$ inches and $<3$ inches diameter.

${ }^{x} 1 \mathrm{lb} /$ acre $=1.1209 \mathrm{~kg} \cdot \mathrm{ha}^{-1}, \mathrm{l} \mathrm{ft}=0.3048 \mathrm{~m}, \mathrm{l}$ inch $=2.54 \mathrm{~cm}$.

"Plot size in the 2001-02 season was a single row, 50-ft-long and in the 2002-03 season, it was a single row, $20 \mathrm{ft}$ long.

"Century' substituted for 'PS 7092' in 2002-03 season because of discontinuation of 'PS 7092'.

"Examination of interactions indicated no differences.

variety or sowing date, nor was there a variety by sowing date interaction. The results were the same for jumbo yields. For medium yields, there was a variety by year interaction. An examination of medium yields for each year indicated no differences between varieties (data not shown). There was no variety by sowing date interaction for medium.

There was a year by variety interaction for seedstems; however, an examination of seedstems in each year indicated no differences (data not shown). There was a sowing date by year interaction, therefore, these results are reported separately for 2002 and 2003 (Table 2). In 2002 and 2003 , the numbers of seedstems were greater on the early sowing date compared with the mid or late sowing dates. There was no variety by sowing date interaction for seedstems.

There was no difference in plant stand based on variety or sowing date and no by year interaction effects, nor was there a variety by sowing date interaction (Table 2 ). In addition, the percentage of onions spaced below 4 inches had by year interactions for variety and a variety by sowing date interaction, but an examination of these interactions showed no difference (data not shown). The variety by date interaction was examined based on individual varieties and sowing dates. Finally, there were no differences among varieties or sowing dates for the percentage of stand above 6.5 inches. There were no three-way interactions, variety by sowing date by year interactions, for any of the tested parameters.

Preliminary work before these studies indicated that seed singulation and sowing date were going to be critical to successful plant establishment in the Vidalia-growing region (Boyhan and Hill, 2002; Boyhan et al., 2001b). Using a belt planter and raw seed proved to be unsatisfactory with seed sown too closely. Even with a vacuum planter, seed singulation continued to be a problem until seeds were coated. Initial work looked at seeding around the time plant beds are sown for transplant production (the end of September), which resulted in almost $100 \%$ seedstems. Additional experiments evaluating growth regulators maleic hydrazide and ethephon to control seedstems also proved fruitless (Boyhan and Hill, 2002). Mowing onion tops to simulate the effect of transplanting also proved fruitless, with tops recovering in 2 weeks to the point that it was difficult to distinguish mowed from unmowed plants.

Differences in seedstem formation from variety is well established (Boyhan et al., 2005; Cramer, 2003). In this study, we did not see seedstem differences among varieties, but early sowing dates influenced seedstems, and this was consistent across all varieties.

Based on this experiment, growers should sow onion seed around 15 Oct., plus or minus 1 week in southeastern Georgia. Earlier plantings are susceptible to high numbers of seedstems, which render these onions unmarketable. Later 
plantings result in plants that are too small to survive the winter. Onions sown on 29 Oct. 2001 were not harvested because of poor stand and size. Smaller onions are more prone to being lost during winter months. An examination of late-sown onions indicates that many were lost to botrytis neck rot (Botrytis alli), which often attacks below the soil line. Growing onions will usually slough off these infected outer leaf scales. It has been observed that larger onions, during cooler winter temperatures when growth has slowed or temporarily stopped, can withstand these infections better than smaller onions. Stands of smaller onions are often observed to loose plants through attrition during cooler winter months regardless of production methoddirect-seeded or transplanted.

There was no difference in total yield between the different fertilizer treatments nor was there any treatment by year interaction (Table 3 ). There was a significant treatment by year interaction for jumbo yields. In 2004 , there was no difference among treatments, but in 2005, there were significant differences between the treatments, with the highest yield using $195 \mathrm{lb} /$ acre total $\mathrm{N}$ with no fertilizer application in December or January (Treatment 3 ). This treatment had significantly greater jumbo yields than the treatment with 150 $\mathrm{lb} /$ acre total $\mathrm{N}$ with an application in January and $\left(\mathrm{NH}_{4}\right)_{2} \mathrm{HPO}_{4}$ as the primary $\mathrm{N}$ source (Treatment 5 ). In addition, (Treatment 3 ) jumbo yield in 2005 was greater than $150 \mathrm{lb} /$ acre $\mathrm{N}$ with and without fertilizer application in January and $10 \mathrm{~N}-4.3 \mathrm{P}-12.4 \mathrm{~K}$ as the primary $\mathrm{N}$ source (Treatments 7 and 8 ).

There were no treatment effects on medium yields nor was there any treatment by year interaction effect on medium. In addition, there were no differences among treatments for number of seedstems, plant stand, or percentage of onions spaced below 4 inches or above 6.5 inches.

Table 3. Effect of different fertilization protocols on yield, graded yield, seedstem formation (flowering), plant stand, and plant spacing in direct-seeded onions for the 2003-04 and 2004-05 seasons. ${ }^{\mathrm{z}}$

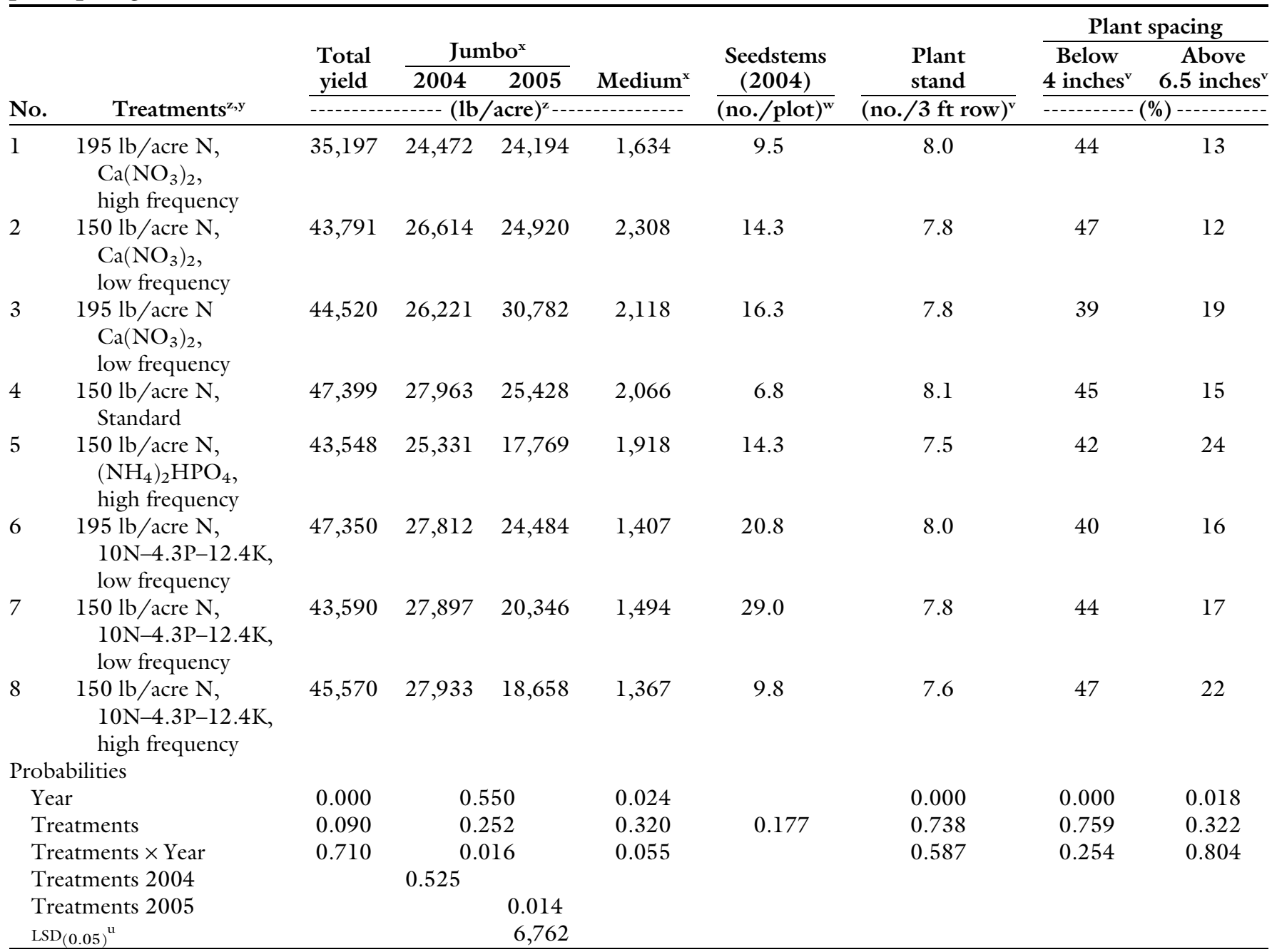

${ }^{2}$ All treatments had $800 \mathrm{lb} /$ acre $\left(1 \mathrm{lb} /\right.$ acre $\left.=1.1209 \mathrm{~kg} \cdot \mathrm{ha}^{-1}\right) 5 \mathrm{~N}-4.3 \mathrm{P}-12.4 \mathrm{~K}$ with $9 \%$ sulfur applied preplant and incorporated.

${ }^{y}$ Listed are the total amount of nitrogen $(\mathrm{N})$ and primary $\mathrm{N}$ source with low frequency indicating no fertilizer application in December or January and high frequency indicating applications in these mo. $\mathrm{Ca}\left(\mathrm{NO}_{3}\right)_{2}=$ calcium nitrate, $\left(\mathrm{NH}_{4}\right)_{2} \mathrm{HPO}_{4}=$ diammonium phosphate.

Jumbo $\geq 3$ inches diameter, medium $\geq 2$ inches and $<3$ inches diameter.

wPlot size was four rows planted on beds on 6-ft centers, $30 \mathrm{ft}$ long in $2003-04$ and $20 \mathrm{ft}$ long in $2004-05$. There was insufficient numbers of seedstems to take meaningful counts in 2005 .

${ }^{\mathrm{v}} \mathrm{l} \mathrm{ft}=0.3048 \mathrm{~m}, \mathrm{l}$ inch $=2.54 \mathrm{~cm}$.

"Fisher's protected least significant difference at $P \leq 0.05$. 
In Georgia, the combined $\mathrm{N}$ requirement for transplants and dry bulb onions is $280 \mathrm{lb} /$ acre, with 130 $\mathrm{lb} /$ acre $\mathrm{N}$ for transplants and the remainder for dry bulbs (Boyhan et al., 2001a). In addition, the Texas Agricultural Extension Service recommends $120 \mathrm{lb} /$ acre $\mathrm{N}$ for dry bulb production from seed (Hall et al., 2000). This suggests that Georgia could reduce $\mathrm{N}$ fertilizer with directseeded production; therefore, rates of 150 and $195 \mathrm{lb} /$ acre $\mathrm{N}$ were used as treatments.

Bolting (flowering) has been a particular problem with direct-seeded onions, particularly when sown early. The low-frequency fertilizer application (no fertilizer in December and January) was an attempt to slow growth during the winter so that plants would be smaller in the spring, reducing the chance of high seedstem numbers.

$\left(\mathrm{NH}_{4}\right)_{2} \mathrm{HPO}_{4}$ was included because of past response during cooler winter months. Although most cultivated soils in southeastern Georgia are high in $\mathrm{P}$, it can become unavailable during cooler months in winter. Onion plants respond to $\left(\mathrm{NH}_{4}\right)_{2} \mathrm{HPO}_{4}$ application with greener and more top growth, although this has not generally translated into greater yields. Additional fertilizers used in this study were $10 \mathrm{~N}-4.4 \mathrm{P}-8.3 \mathrm{~K}$, $5 \mathrm{~N}-4.3 \mathrm{P}-12.4 \mathrm{~K}$, and $\mathrm{Ca}\left(\mathrm{NO}_{3}\right)_{2}$, all of which are commonly used fertilizers in this area.

With the exception of differences in jumbo yield in 2005 , onion yield was largely the same across these fertilizer treatments, suggesting that $150 \mathrm{lb} /$ acre $\mathrm{N}$ would be adequate for direct-seeded onion production. This would eliminate all of the fertilizer used in transplant production, along with the associated costs.

Transplant cost, both production and setting, is estimated at $\$ 555.00 /$ acre, which would be eliminated with direct seeding (Boyhan et al., 200la). This cost represents about $16 \%$ of the total variable and fixed costs. The onion budget for Georgia was developed assuming an average yield of $20,000 \mathrm{lb} /$ acre with a potential range of 10,000 to 40,000 $\mathrm{lb} / \mathrm{acre}$ for a transplanted crop. These experiments fall within this yield range, suggesting that direct seeding would not result in reduced yields compared with transplanting.
Transplant production dominates onion production in Georgia for several reasons. In the early 1980s, onion production was evenly split between transplants and directseeding, but a couple of years of single-digit temperatures quickly resulted in almost all onion production going to transplants (D. Pickenpaugh, pers. comm.). Transplants, because they are set deeper in the soil, are better able to survive severely cold weather compared with direct-seeded onions, which develop at or near the soil surface.

In addition, transplant production results in a perfect stand, whereas with direct-seeded onions, even under the best of circumstances, there are going to be some onions misplanted, resulting in skips or spacing that is too close. This was evident in these experiments (Tables 2 and 3 ). Because of the possibility of misplanted onions, growers are advised to exercise care with direct seeding to maximize success. Using a vacuum planter with coated seeds to insure good singulation, coupled with proper land preparation and timely water applications, is critical to success with direct seeding. Another advantage of transplants is weed control. The primary herbicide, oxyfluorfen, can be used at the maximum rate for onions immediately after transplanting because the plant tops have been removed. Removal of tops reduces herbicide damage to the plants. In direct-seeded onions, the maximum rate of oxyfluorfen can be used, but it has to be applied at lower rates in multiple applications. Weed control success in direct-seeded onions is critically dependent on herbicide application timing.

Direct-seeded onions have some advantages as well, with the primary one being cost savings because transplant production is not needed. This includes all of the chemicals, equipment use, and labor.

In addition, onions in southeastern Georgia are hand transplanted with migrant labor. The entire Vidalia onion crop of 12,000 to 14,000 acres is hand transplanted in an 8- to 9week period. This requires a large labor force. Although this labor force has been readily available, there is concern that future labor availability may be limited. For this reason, growers should become familiar with direct seeding, if for no other reason than to gain experience with this production method in case there is a labor shortage.

In conclusion, onion from transplants will likely continue to dominate production in the Vidalia region of southeastern Georgia for the foreseeable future. Growers, however, do have an alternative in direct seeding that can save money. In addition, if labor availability becomes scarce, direct seeding can be a viable alternative that can be successfully adopted.

\section{Literature cited}

Al-Abdulsalam, M.A. and A.F. Hamaiel. 2004. Effect of planting dates and compound fertilizers on growth, yield and quality of Hassawi onion under Al-Hassa oasis conditions. Scientific J. King Faisal Univ. (Basic Appl. Sci.). 5:65-79.

Bhonde, S.R., A.B. Chougule, and N.B. Singh. 2001. Studies on the effect of age of seedlings and date of harvesting on yield and quality of onion during late kharif season. Nwsl. Natl. Hort. Res. Dev. Foundation 21:27-30.

Boyhan, G. and C.R. Hill. 2002. Direct seeding Vidalia onions. Univ. Georgia Coop. Res. Ext. Publ. No. 3-2002:9-12.

Boyhan, G.E., D.M. Granberry, and W.T. Kelley. 2001a. Onion production guide. Univ. Georgia Bull. No. 1198.

Boyhan, G.E., A.C. Purvis, W.M. Randle, R.L. Torrance, M.J.I. Cook, G. Hardison, R.H. Blackley, H. Paradice, C.R. Hill, and J.T. Paulk. 2005. Harvest and postharvest quality of short-day onions in variety trials in Georgia, 2000-03. HortTechnology 15:694-706

Boyhan, G.E., R.L. Torrance, D.E. Curry, and C.R. Hill. 2001b. Preliminary results of direct-seeded Vidalia onions. Univ. Georgia Coop. Res. Ext. Publ. No. 32001:12-13.

Brewster, J.L. 1990. The influence of cultural and environmental factors on the time of maturity of bulb onion crops. Acta Hort. 267:289-296.

Cramer, C.S. 2003. Performance of fallsown onion cultivars using four seeding dates. J. Amer. Soc. Hort. Sci. 128:472478.

Gamie, A.A., G.H.A. El-Rhim, M.K. Imam, and A.E. Abdoh. 1996. Effect of sowing dates on yield and bulb quality of some onion cultivars grown by direct seeding. Assiut J. Agr. Sci. 27:101-110. 
Gomez, K.A. and A.A. Gomez. 1984. Statistical procedures for agricultural research. Wiley, New York.

Hall, K.D., R.L. Holloway, and D. Smith. 2000. Texas crop profile onions. Texas A\&M Univ. Publ. E-18.

Khokhar, K.M., N. Kaska, S.I. Hussain, K.M. Qureshi, and T. Mahmood. 1990. Effect of different sowing dates, direct seeding and transplanting of seedling on maturation, bulb weight and yield in onion (Allium cepa) cultivars. Indian J. Agr. Sci. 60:668-671.

Kissel, D. 2003. Soil test handbook for Georgia. University of Georgia, Athens.

Leskovar, D.I., M. Cantamutto, P. Marinangelli, and E. Gaido. 2004. Effects of direct-seeded, bareroot, and various tray seedling densities on the growth dynamics and yield of long-day onion. Agronomie 24:35-40.
Movalia, A.G., B.B. Kaneria, V.D. Khanpara, K.V. Jadav, and R.K. Mathukia. 1999. Response of direct seeded and transplanted onion (Allium cepa L.) to dates of sowing and nitrogen levels. Gujarat Agr. Univ. Res. J. 25:90-93.

U.S. Department of Agriculture. 1995. United States standards for grades of Bermuda-Granex-Grano type onions. U.S. Dept. of Agriculture, Washington, DC. 